\title{
EAST AFRICAN DEVELOPMENT BANK (EADB)
}

Established originally under the Treaty for East African Co-operation in 1967 with Kenya, Tanzania and Uganda as signatories, a new Charter for the Bank (with the same signatories) came into force in 1980. Under the original Treaty the Bank was confined to the provision of financial and technical assistance for the promotion of industrial development in member states but with the new Charter its remit was broadened to include involvement in agriculture, forestry, tourism, transport and the development of infrastructure, with preference for projects which promote regional co-operation.

Official language: English.

Headquarters: 4 Nile Avenue, Kampala, Uganda.

Website: http://www.eadb.org

Chairman of the Board: Christopher Kassami (Uganda).

\section{ECONOMIC COMMUNITY OF CENTRAL AFRICAN STATES (CEEAC)}

The Economic Community of Central African States (Communauté Economique des Etats de l'Afrique Centrale) was established in 1983 to promote regional economic co-operation and to establish a Central African Common Market. Plans were announced in Jan. 2004 for a free trade zone to be set up by the end of 2007.

Members. Angola, Burundi, Cameroon, Central African Republic, Chad, Democratic Republic of the Congo, Republic of the Congo, Equatorial Guinea, Gabon, Rwanda, São Tomé e Príncipe.

Headquarters: BP 2112, Libreville, Gabon.

Website: http://www.ceeac.eccas.org

President: Denis Sassou-Nguesso (Republic of the Congo).

Secretary-General: Louis Sylvain-Goma (Republic of the Congo).

\section{ECONOMIC COMMUNITY OF WEST AFRICAN STATES (ECOWAS)}

Founded in 1975 as a regional common market, and now aiming to operate a single currency zone by the end of 2005 , ECOWAS later also became a political forum involved in the promotion of a democratic environment and the pursuit of fundamental human rights. In July 1993 it revised its treaty to assume responsibility for the regulation of regional armed conflicts, acknowledging the inextricable link between development and peace and security. Thus it now has a new role in conflict management and prevention through its Mediation and Security Council, which monitors the moratorium on the export, import and manufacture of light weapons and ammunition. However, it still retains a military arm, ECOMOG. It is also involved in the war against drug abuse and illicit drug trafficking.

Members. Benin, Burkina Faso, Cape Verde, Côte d'Ivoire, The Gambia, Ghana, Guinea, Guinea-Bissau, Liberia, Mali, Niger, Nigeria, Senegal, Sierra Leone, Togo. 